\title{
Phyllanthus L. (Phyllanthaceae) em Pernambuco, Brasil ${ }^{1}$
}

\author{
Marcos José da Silva ${ }^{2,4}$ e Margareth Ferreira de Sales ${ }^{3}$
}

Recebido em 6/02/2006. Aceito em 3/08/2006

\begin{abstract}
RESUMO - (Phyllanthus L. (Phyllanthaceae) em Pernambuco, Brasil). O estudo foi baseado na análise morfológica de materiais herborizados e observação em campo. Foram registradas 17 espécies diferenciadas, principalmente, através do número e forma das sépalas, número e união dos estames, além do sexo da inflorescência e ornamentação da testa das sementes. Dessas espécies, seis (P. amarus Schum. \& Thonn., P. tenellus Roxb., P. caroliniensis Walt. subsp. caroliniensis, P. niruri L., P. orbiculatus L.C. Rich. e P. stipulatus (Raf.) Webster) apresentam ampla distribuição no Estado, quatro (P. chacoensis Morong, P. klotzschianus Müll. Arg., $P$. heteradenius Müll. Arg., P. claussenii Müll. Arg.) restringiram-se a zona das Caatingas, sendo $P$. chacoensis Morong restrita à vegetação ripária do vale do rio São Francisco e as demais (P. acuminatus Vahl, P. subemarginatus Müll. Arg., P. minutulus Müll. Arg., P. hypoleucus Müll. Arg., P. juglandifolius Willd., P. urinaria L. e P. grandyi M.J. Silva \& M.F. Sales) são de ambientes florestais da zona da Mata, podendo ainda alcançar as florestas montanas, "brejos” de Altitude, do interior do Estado. Chave para identificação, comentários sobre afinidades e distribuição geográfica, bem como ilustrações, são fornecidas.
\end{abstract}

Palavras-chave: Phyllanthus, Euphorbiaceae, taxonomia, Diversidade

\begin{abstract}
Phyllanthus L. (Phyllanthaceae) in Pernambuco State, Brazil). This study was based on morphological analysis of dry material and field observations. The 17 species found in Pernambuco are recognized by sepal number and shape, number and fusion of the stamens, inflorescence sex and seed coat ornamentation. Six species (P. amarus Schum. \& Thonn., P. tenellus Roxb., P. caroliniensis Walt. subsp. caroliniensis, P. niruri L., P. orbiculatus L.C. Rich. and P. stipulatus (Raf.) Webster) are widely distributed in Pernambuco; four (P. chacoensis Morong, P. klotzschianus Müll. Arg., P. heteradenius Müll. Arg., P. claussenii Müll. Arg.) are restricted to the caatinga biome, where $P$. chacoensis is restricted to riparian vegetation of the São Francisco River. The other species ( $P$. acuminatus Vahl, P. subemarginatus Müll. Arg., P. minutulus Müll. Arg., P. hypoleucus Müll. Arg., P. juglandifolius Willd., P. urinaria L. and P. grandyi M.J. Silva \& M.F. Sales) are found in forest habitats of the "Zona da Mata", including montane forests or "brejos de altitude". Identification keys, comments on morphological relationships and geographic distribution and illustrations are provided.
\end{abstract}

Key words: Phyllanthus, Euphorbiaceae, taxonomy, diversity

\section{Introdução}

Phyllanthaceae, táxon recentemente desmembrado de Euphorbiaceae s.l., é uma das famílias mais diversificadas de Malpighiales (clado Eurosidae I) com cerca de 2.000 espécies e 59 gêneros dispersos por todo o globo (Chase et al. 2002; Samuel et al. 2005). Inclui espécies de hábitos variados, sem látex, inflorescências cimosas, flores diclinas, em geral com disco, gineceu 3 (raro 4)-carpelar, 3 (4)-locular, com lóculos usualmente bi-ovulados, frutos comumente capsulares e sementes sem carúncula.

Phyllanthus destaca-se pelo elevado número de espécies (ca. 800), dispersas por todas as regiões do mundo, e pela complexidade taxonômica (Webster
1956; 2002ab). Nos neotrópicos está representado por mais de 200 espécies (Webster 2002b). No Brasil, ocorrem aproximadamente 107 espécies, das quais, cerca de um quarto figuram principalmente nos campos rupestres, cerrados e caatingas. Este gênero subordina plantas de hábito variado, principalmente herbáceo (70\%), com ramificação filantoíde ou não filantoíde, flores gamossépalas em inflorescências cimosas, disco usualmente presente em ambas as flores, comumente inteiro nas pistiladas e segmentado nas estaminadas, frutos capsulares, mais raramente bacáceos, e sementes usualmente trígonas e ornamentada.

Phyllanthus recebeu atenção de diversos estudiosos (Müller 1866; Rossignol et al. 1987), especialmente nas Américas (Webster 1956; 1957;

\footnotetext{
1 Parte da Dissertação do primeiro Autor

2 Universidade Federal Rural de Pernambuco, Programa de Pós-Graduação em Botânica (CNPq n. 130108/2004-9)

3 Universidade Federal Rural de Pernambuco, Departamento de Biologia, Área Botânica, Rua Dom Manoel de Medeiros s.n., 52171-900 Dois Irmãos, Recife, PE, Brasil (mfsales.2002@ig.com.br)

4 Autor para correspondência: marcos_agrorural@hotmail.com
} 
1958; 2002ab; 2003; Webster \& Burch 1967). No Brasil, estudos abordando a taxonomia de Phyllanthus são escassos. No entanto, merecem menção os de Müller (1873), na "Flora Brasiliensis", que inclui 71 espécies em 11 seções; de Santiago (1988), que revisou $P$. sect. Choretropsis; de Webster (2002b), que elaborou uma sinopse das espécies brasileiras do subgênero Phyllanthus. Além destes, refereciam-se as floras locais: Rio Grande do Sul (Allem 1977), Santa Catarina (Smith \& Downs 1959), Serra do Cipó, em Minas Gerais (Cordeiro 1992), Pico das Almas, na Bahia (Cordeiro 1995), Chapada Diamantina, na Bahia (Torres et al. 2003) e no bioma caatinga de Pernambuco (Silva \& Sales 2004).

O presente trabalho objetivou reconhecer a diversidade de Phyllanthus no Estado de Pernambuco.

\section{Material e métodos}

Realizaram-se coletas de 2004 a 2005, nas diferentes zonas fitogeográficas pernambucanas, para obtenção de material botânico e observação das populações. O material coletado, após processamento, foi depositado no herbário Professor Vasconcelos Sobrinho (PEUFR) da Universidade Federal Rural de Pernambuco. A identificação dos táxons baseou-se na literatura já mencionada neste artigo e fotografias das coleções-tipo. A padronização das estruturas vegetativas e reprodutivas baseou-se em Radford et al. (1974). As informações contidas nos rótulos das exsicatas dos herbários: EAC, EAN, ESA, CEPEC, HAS, HB, HRB, HRCB, HUEFS, IBGE, INPA, IPA, JPB, PACA, PEUFR, PMSP, R, RB, SJRP, SP, SPSF, TEPB, UB, UFP, VIC, listados conforme Holmgren et al. (1990), auxiliaram os comentários e distribuição das espécies. Uma listagem completa das exsicatas analisadas está disponível com o primeiro autor.

\section{Resultados e discussão}

Phyllanthus L., Sp. pl. 981. 1753.

Espécie Tipo: Phyllanthus niruri L.

Ervas, arbustos, raro árvores, monóicas raro dióicas. Padrão de ramificação não filantóide, com ramos persistentes variadamente ramificados, ou filantóide com ramos, em geral decíduos, plagiotrópicos e dispostos espiraladamente ao longo do ramo principal (caule), ou de suas ramificações, apresentando aspecto pinatiforme (assemelhando-se a uma folha composta pinada) ou bipinatiforme (assemelhando-se a uma folha composta bipinada), modificados ou não em cladódios. Catafilos em geral presentes na inserção dos ramos. Folhas comumente alternas (opostas em $P$. almadensis Müll. Arg.), inteiras, pecioladas, estipuladas, freqüentemente glabras, discolores e broquidodrómas. Inflorescências axilares, usualmente cimosas, címulas unissexuais ou bissexuais ou, às vezes, flores solitárias. Flores monoclamídeas, gamossépalas, sépalas 4-6, verde-esbranquiçadas, amareladas, esbranquiçadas ou róseas. Flores estaminadas sésseis ou pediceladas; disco extra-estaminal usualmente segmentado, raro inteiro; estames (2) 3-6, livres, parcial a completamente unidos; anteras com rimas horizontais, oblíquas a verticais. Flores pistiladas sésseis ou pediceladas; disco freqüentemente inteiro; ovário 3-carpelar, 3-locular (raro 2-locular) com dois, raro um (P. chacoensis Morong) óvulo por lóculo; estiletes 3, livres ou unidos, bífidos a bilobados, estigmas agudos a capitados. Faixa central presente ou ausente, nas sépalas de uma ou ambas as flores; se presentes, em geral da mesma forma que as das sépalas, mas com coloração diferente das mesmas. Fruto capsular septicida, raro bacáceo ou drupáceo (P. chacoensis). Sementes trígonas, plano-convexas ou reniformes, testa lisa ou ornamentada; hilo triangular a circular.

Chave para as espécies de Phyllanthus

1. Ramos modificados em cladódios

9. P. klotzschianus

1. Ramos não modificados em cladódios

2. Sépalas estaminadas 4

3. Estames 2; flores com disco 17. P. gradyi

3. Estames 4; flores desprovidas de disco 4. P. chacoensis

2. Sépalas estaminadas 5 ou 6

4. Sépalas estaminadas 5

5. Estames sempre livres

6. Estames 5; anteras com rimas suboblíquas 15. P. tenellus

6. Estames 3; anteras com rimas horizontais 
7. Ramos com emergências papilosas; pedicelo pistilado $1,8-3 \mathrm{~cm}$

7. P. hypoleucus

7. Ramos lisos; pedicelo pistilado 1,4-10,5 mm

8. Ervas; sépalas pistiladas cartáceas

6. P. heteradenius

8. Subarbustos; sépalas pistiladas membranáceas

14. P. subemarginatus

5. Estames parcial a completamente unidos

9. Árvore; estames 4-6; disco estaminado inteiro

8. P. juglandifolius

9. Erva ou subarbusto; estames 2-3; disco estaminado segmentado

10. Estames 2; disco estaminado com segmentos lisos

10. P. minutulus

10. Estames 3; disco estaminado com segmentos verruculosos

11. Limbo foliar de base oblíqua; estames livres a parcialmente unidos; sementes verruculosas

11. P. niruri

11. Limbo foliar de base simétrica; estames completamente unidos; sementes estriadas

12. Címulas bissexuais com duas flores, uma estaminada e outra pistilada

2. P. amarus

12. Címulas unissexuais estaminadas dispostas na metade proximal dos ramos, e flores pistiladas solitárias encerrando os mesmos

13. P. stipulatus

4. Sépalas estaminadas 6

13. Estames unidos

14. Planta arbórea ou arbustivo-arbórea; limbo foliar 2,1-4,5×1,5-2,6 cm, oval a ovalelíptico, ápice acuminado

1. P. acuminatus

14. Planta herbácea; limbo foliar 10-14×2,8-3,8 mm, oblongo a oblongo-espatulado, ápice arredondado

16. P. urinaria

13. Estames livres

15. Arbustos; segmentos do disco estaminado discretamente foveolados

5. P. claussenii

15. Ervas; segmentos do disco estaminado lisos ou discretamente papilosos

16. Limbo foliar elíptico a largamente elíptico; pedicelo estaminado 0,9-1,2 mm, pistilado 0,7-0,8 $\mathrm{mm}$; sépalas pistiladas oblongo-espatuladas

3. P. caroliniensis subsp. caroliniensis

16. Limbo foliar orbicular a largamente orbicular; pedicelo estaminado 2,3-4 mm, pistilado 3-3,1 mm; sépalas pistiladas oblongas a lineares . 12. P. orbiculatus

Phyllanthus acuminatus Vahl, Symb. Bot. 95. 1791.

Fig. 1-6

Planta arbórea ou arbustivo-arbórea, com 3-6 m. Ramificação filantóide; ramos bipinatiformes, angulosos, lenticelados, glabros a puberulentos. Catafilos ca. $2 \mathrm{~mm}$, triangulares. Estípulas 1,3-1,4 mm, triangulares. Pecíolo 1,4-2 mm, puberulento. Limbo foliar 2,1-4,5×1,5-2,6 cm, membranáceo, oval a ovalelíptico, base obtusa ou arredondada, ápice acuminado. Címulas bissexuais, com 5-6 conjuntos estaminados, cada um com 4-6 flores, flor pistilada solitária na parte central; brácteas elípticas. Flores estaminadas: pedicelo 2,9-4 mm, filiforme; sépalas 6, bisseriadas; lobos externos ca. $1 \mathrm{~mm}$, oblongo-elípticos; internos ca. $1 \mathrm{~mm}$, ovais; disco com três segmentos reniformes, foveolados; estames 3, unidos; anteras cordiformes, rimosas horizontalmente. Flores pistiladas: pedicelo 8-11 mm anguloso; sépalas 6 , bisseriadas; lobos externos 1,6-1,8 $\mathrm{mm}$, oblongo-elípticos; internos 1,1-1,5 mm, elípticos a trulados; disco cupuliforme, 3-lobado; ovário oblato; estiletes livres, bilobados. Cápsula 3,9-4 mm, ca. $5 \mathrm{~mm}$ diâm., oblata. Sementes 3-3,2×2-2,5 mm, plano-convexas, superfície areolada, castanho-claro, lustrosas.

Material Selecionado: BRASIL. Pernambuco: Águas Belas, 19/XI/2004, fl. fr., Silva 572 (PEUFR); Altinho, 10/IV/2002, fl. fr., Silva 189 (PEUFR); Belo Jardim, 17/X/2000, fr., Cantarelli 488 (PEUFR); Bonito, 21/V/1996, fl. fr., Lira 178 (PEUFR).

Exclusiva das Américas, ocorrendo desde o México até o Norte da Argentina incluindo Antilhas. Cresce em florestas secundárias e em matas de galerias do cerrado (Webster 2003; Silva \& Sales 2004). No Brasil é referida para as regiões Norte, Centro-Oeste e Nordeste e Sudeste. Em Pernambuco ocorre floresta atlântica e nos "brejos de Altitude", na borda da mata, 
em solos úmidos. Distingue-se das demais espécies estudadas pelos ramos bipinatiformes, flores hexâmeras com sépalas bisseriadas, estames (3) unidos, além das sementes plano-convexas. Assemelha-se a P. brasiliensis subsp. brasiliensis (norte da América do Sul) por compartilharem o mesmo padrão de ramificação, tipo de inflorescência e de sementes. Entretanto, P. acuminatus diferencia-se pelo disco estaminado com três segmentos e ausência de címulas nos ramos principais. $\mathrm{Na}$ subespécie brasiliensis o disco estaminado é anular e as címulas estão presentes nos ramos principais. É reconhecida pelos vernáculos de "tinguí" e "mata peixe" em Pernambuco e Bahia. Floresce e frutifica de fevereiro a junho e de agosto a novembro.

Phyllanthus amarus Schum. \& Thonn., Kongl. Dasnke Vidensk. Skr. 4: 195-196. 1829.

Fig. 7-12

Erva ou subarbusto $14-70 \mathrm{~cm}$, anual. Ramificação filantóide; ramos 3,2-9 $\mathrm{cm}$, pinatiformes, angulosos. Catafilos 0,8-1 mm, triangulares. Estípulas ca. $1 \mathrm{~mm}$, oval-lanceoladas. Pecíolo ca. 0,4 mm. Limbo foliar 7-10 ×2,5-4 mm, membranáceo, oblongo a oblongooboval, base arredondada, ápice arredondado. Címulas bissexuais, com uma flor estaminada e uma pistilada, dispostas ao longo dos ramos; brácteas lineares. Flores estaminadas: pedicelo ca. $0,5 \mathrm{~mm}$, cilíndrico; sépalas 5 , oblongo-elípticas, ápice cuspidado, faixa central presente; disco com 5 segmentos livres, orbicularlobados; estames 3 , unidos, anteras com rimas oblíquas. Flores pistiladas: pedicelo ca. $0,9 \mathrm{~mm}$, cilíndrico; sépalas 5 , oblongas a oblongo-elípticas, semelhante às estaminadas; disco 5-segmentado; ovário globoso; estiletes livres, bífidos; estigmas levemente bilobados. Cápsula 1-1,3×1,7-1,8 mm, oblata. Sementes $1 \times 1 \mathrm{~mm}$, trígonas; hilo circular, subterminal; testa com 6 (5 ou 7) estrias dorsais arranjadas longitudinalmente e 3-4 estrias semiconcêntricas, em cada uma das faces laterais, castanho-claro, lustrosas.

Material selecionado: BRASIL. Pernambuco: Alagoinha, 9/IV/2002, fl. fr., Silva 172 (PEUFR); Barreiros, 27/IX/2004, fl. fr., Silva 534 (PEUFR); Belém de Maria, 14/VI/2003, fl. fr., Silva 340 (PEUFR); Betânia, 25/VIII/2001, fl. fr., Silva 119 (PEUFR).

Espécie cosmopolita. Nas Américas é encontrada desde os Estados Unidos até a Argentina, incluindo Antilhas (Webster 1970; 2002b). No Brasil distribui-se da região Norte a Sul, crescendo em todos os tipos de vegetação, em ambientes úmidos, ou ainda como ruderal ou invasora em áreas agricultáveis. Ocorre em todo o Estado, em locais úmidos, sendo ainda comum em jardins, frestas de calçadas e em áreas agricultáveis. Phyllanthus amarus assemelha-se a P. minutulus e a $P$. stipulatus. Entretanto, difere de P. minutulus por este apresentar dois estames (três em P. amarus), címulas unissexuais estaminadas e flores pistiladas solitárias (vs. címulas bissexuais), sépalas estaminadas obovais (vs. oblongo-elípticas) e de $P$. stipulatus pelas sementes com estrias transversais arranjadas em fileiras longitudinais (vs. estrias longitudinais), anteras com rimas horizontais (vs. oblíquas) e sépalas pistiladas obovais (vs. oblongo-elíptico). É conhecida popularmente como "quebra-pedra" ou "ervapombinha". Floresce e frutifica durante todo ano.

Phyllanthus caroliniensis Walt. subsp. caroliniensis, Flora Caroliniana p.228. 1788.

Fig. 13-18

Erva 5-30 cm, anual. Ramificação não filantóide; ramos laterais 5-9 cm, cilíndricos, arranjados disticamente conferindo a planta aspecto de folha bipinada. Catafilos ausentes. Estípulas 1-1,1 mm, triangulares, levemente auriculadas, margens denticuladas. Pecíolo 1-1,3 mm. Limbo foliar 9-15×5-8 mm, membranáceo, elíptico a largamente elíptico, base aguda, ápice obtuso. Címulas bissexuais, na axila da folhas e inserção dos ramos, com (1-)2 flores estaminadas e (1-)2 pistilada; brácteas triangulares. Flores estaminadas: pedicelo 0,9-1,2 mm, cilíndrico; sépalas 6 , obovais a suborbiculares, raro elípticas, ápice arredondado; estames 3, livres, anteras com rimas horizontais; disco com seis segmentos obtriangulares, superfície lisa. Flores pistiladas: pedicelo ca. 0,8 $\mathrm{mm}$; sépalas 6 , oblongo-espatuladas, faixa central presente, verde-claras a vináceas; disco cupuliforme; ovário depresso-oval; estiletes livres, bífidos; estigmas subcapitados. Cápsula ca. $1 \mathrm{~mm}$ e 1,7-1,9 mm diâm., depresso-oval. Sementes 0,9-1 $\times 0,6-0,8 \mathrm{~mm}$, trígonas; hilo obtriangular, terminal; testa com 7-8 fileiras de verrugas arranjadas longitudinalmente na face dorsal e 4-6 semiconcêntricamente nas faces laterais, castanho-claro a escuro, lustrosas.

Material selecionado: BRASIL. Pernambuco: Barreiros, 27/IX/2004, fl. fr., Silva 555 (PEUFR); Bonança, III/1924, fl. fr., Pickel 662 (SP); Brejo da Madre de Deus, 12/III/04, fl. fr., Silva 410 (PEUFR); Caruaru, 25/VII/2001, fl. fr., Silva 108 (PEUFR); Glória do Goitá, 10/VII/2004, fl. fr., Silva 480 (PEUFR). 


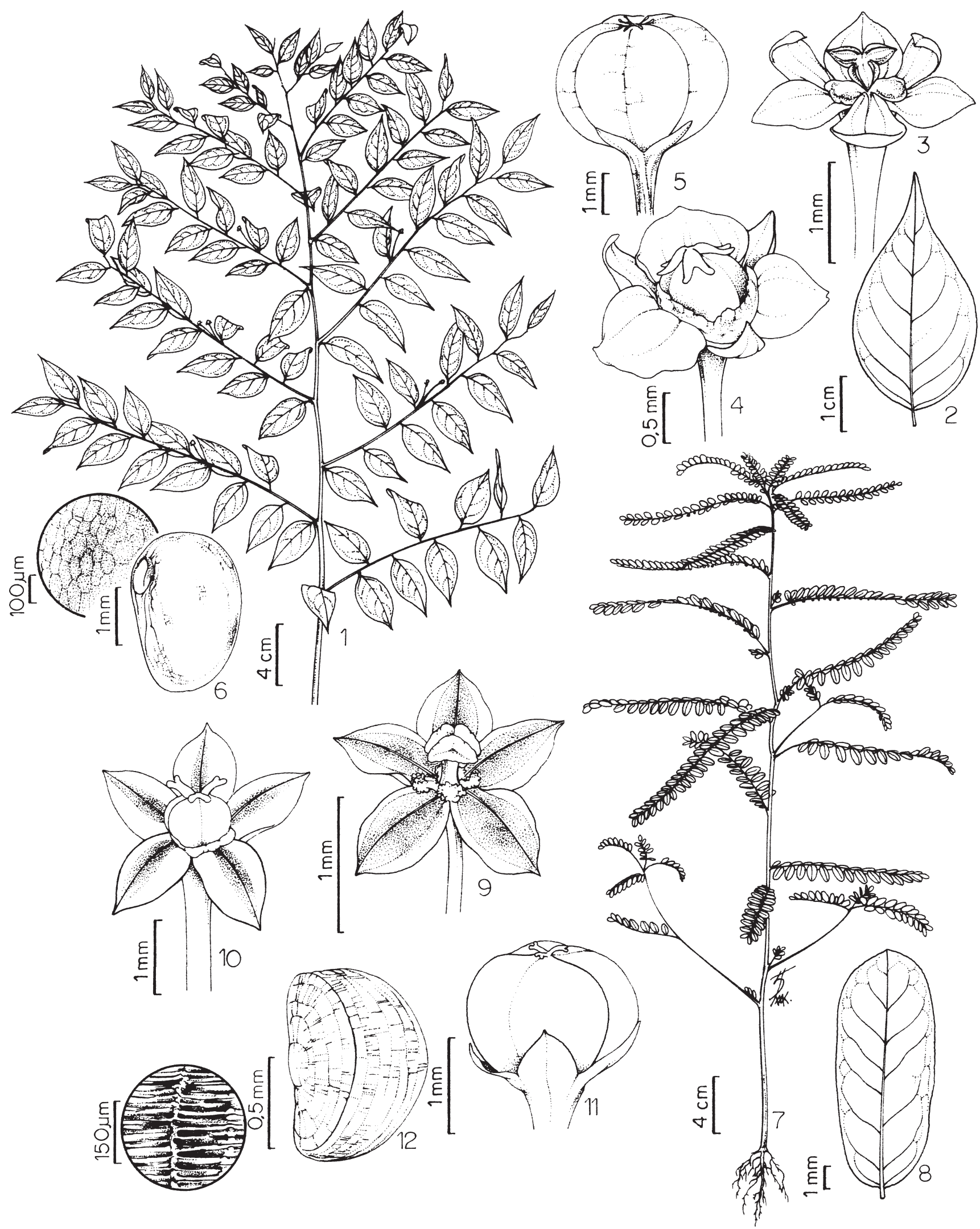

Figuras 1-6. Phyllanthus acuminatus Vahl 1. Ramo florido. 2. Foliar. 3. Flor estaminada. 4. Flor pistilada. 5. Fruto. 6. Aspecto geral da semente e detalhe de sua ornamentação (Silva 572). Figuras 7-12. P. amarus Schum. \& Thonn. 7. Hábito. 8. Folha. 9. Flor estaminada. 10. Flor pistilada. 11. Fruto. 12. Aspecto geral da semente e detalhe de sua ornamentação (Silva 428). 
Ocorre amplamente nas Américas (Webster 1970). No Brasil distribui-se da região Norte a Sul, na floresta atlântica, no cerrado (mata de galeria), na caatinga e nas florestas montanas. Em Pernambuco ocorre em diversos ambientes, incluindo áreas agricultáveis e ruderais, em lugares úmidos ou encharcados. Pode ser reconhecida pelos ramos de disposição dística, quase do mesmo tamanho, conferindo aspecto de uma folha bipinada e pelo cálice hexâmero e unisseriado em ambas as flores. Assemelhasse a $P$. heteradenius por ambas compartilharem o mesmo padrão de ramificação (não filantóide), flores dispostas tanto nas axilas das folhas quanto na inserção dos ramos, o mesmo número de estames (três) e abertura das anteras (horizontal). Porém, P. heteradenius distingue-se pelas flores de ambos os sexos com cinco sépalas (seis em P. caroliniensis subsp. caroliniensis), disco estaminado com segmentos elípticos (vs. segmentos obtriangulares) e sementes reticuladopunctadas (vs. verrucosas).

Phyllanthus chacoensis Morong, Ann. New York Acad. Sci VII: 218. 1892.

Fig. 19-25

Árvore 5-6 m. Ramificação filantóide; ramos, angulosos, lenticelados. Catafilos ca. $2 \mathrm{~mm}$, largamente triangulares. Estípulas 1,2-1,6 mm, triangulares, fimbriadas, amarrozadas. Pecíolo 1,8-2 mm. Limbo foliar 2,5-4×2,1-2,8 cm, cartáceo, largamente elíptico a orbicular ou oboval, ápice arredondado a retuso, base obtusa. Inflorescências estaminadas e pistiladas caulifloras, tirsiformes; as estaminadas 2,2-2,4 mm, com 9-12 conjuntos de címulas, cada címula com 3 flores, subtendida por uma bráctea, oval-deltóide, acuminada, cada flor envolta por uma bractéola, lanceolada; inflorescências pistiladas semelhantes às estaminadas, 8-10 mm, com 8-10 conjuntos de címulas, cada címula com 1-2 flores. Flores estaminadas: pedicelo 1,2-1,8 $\mathrm{mm}$; sépalas 4, oblongo-espatuladas, ápice arredondado, fimbriadas; estames 4 , subsésseis, anteras oblongas, rimas verticais. Flores pistiladas: pedicelo 3-3,2 mm, filiforme; sépalas 4, semelhantes às estaminadas; ovário elipsóide, avermelhado; carpelos 2, um óvulo por lóculo; estiletes profundamente bífidos, ascendentes e recurvados. Fruto drupáceo 7,6-7,8×5-5,2 mm, elipsóide.

Material examinado: BRASIL. Pernambuco: Petrolina, 15/III/1983, fl. fr., Fotius 3652 (IPA).

Exclusiva da América do Sul, sendo registrada para as regiões chaquenha (Argentina e Paraguai) (Lourteig \& O’Donell 1942) e Nordeste do Brasil. Neste estudo foi verificada apenas no domínio do semi-árido, na vegetação ripária das margens do rio São Francisco. Entre as espécies estudadas é a única desprovida de disco floral, com sépalas e estames em número de quatro, inflorescências caulifloras, ovário bi-carpelar e fruto com uma semente por lóculo. Apresenta semelhanças morfológicas com Phyllanthus elsie Urban (chaco Argentino, Antilhas) embora, se diferencie por esta ser dióica e apresentar ovário 3-locular com estiletes unidos em uma coluna e frutos oblatos esferoidais.

Phyllanthus claussenii Müll. Arg., Linnaea 32: 40. 1863.

Fig. 26-31

Arbusto 0,8-1,6 m. Ramificação não filantóide; ramos patentes a subpatentes, às vezes flexuosos. Estípulas ca. 1,1 mm, triangulares. Pecíolo ca. $1,2 \mathrm{~mm}$. Limbo foliar 6-16×7-11 mm, membranáceo, largamente elíptico a orbicular, base obtusa, ápice arredondado e apiculado. Inflorescência cimosa bissexual, com três címulas estaminadas e uma flor pistilada central longo pedunculada; címulas estaminadas com 2-3-flores; brácteas lineares. Flores estaminadas: pedicelo 1,2-1,6 mm, filiforme; sépalas 6, elípticas, ápice arredondado; disco com 6 segmentos obtriangulares de superfície discretamente foveolada; estames 3 , livres, anteras com tecas divergentes, rimas horizontais. Flores pistiladas: pedicelo $6,7-12 \mathrm{~mm}$, filiforme; sépalas 6, elíptico-obovais, ápice agudo a obtuso, faixa central presente; disco pateliforme; ovário depresso-globoso; estiletes livres, bífidos. Cápsula 1-1,2×1,9-2,1 mm, oblata. Sementes 1,7-1,8×1,2-1,3 mm, trígonas, hilo arredondado; testa com verruculas alinhadas longitudinalmente na face dorsal e semiconcêntricamente nas faces laterais, castanho-claras, lustrosas.

Material examinado: BRASIL. Pernambuco: Arcoverde, 2/VII/2004, fl. fr., Silva 450 (PEUFR); São José do Belmonte, 9/IV/2002, fl. fr., Laurênio 1823 (PEUFR).

Restrita ao Brasil, nas regiões Nordeste (CE, BA, PB, PE), Sudeste (MG, SP, e ES), Centro-Oeste (DF) e Sul (PR), crescendo no cerrado, campo rupestre, carrasco e caatinga (Webster 2002b; Silva \& Sales 2004). Em Pernambuco ocorre na zona das Caatingas, em vegetação de caatinga, em locais abertos. Caracteriza-se pelo porte arbustivo, densamente ramificado, número de sépalas (seis) em ambas as flores, estames (três) livres e disco glandular 6-segmentado, o que a distingue das demais espécies estudadas. É semelhante a P. subemarginatus, embora 


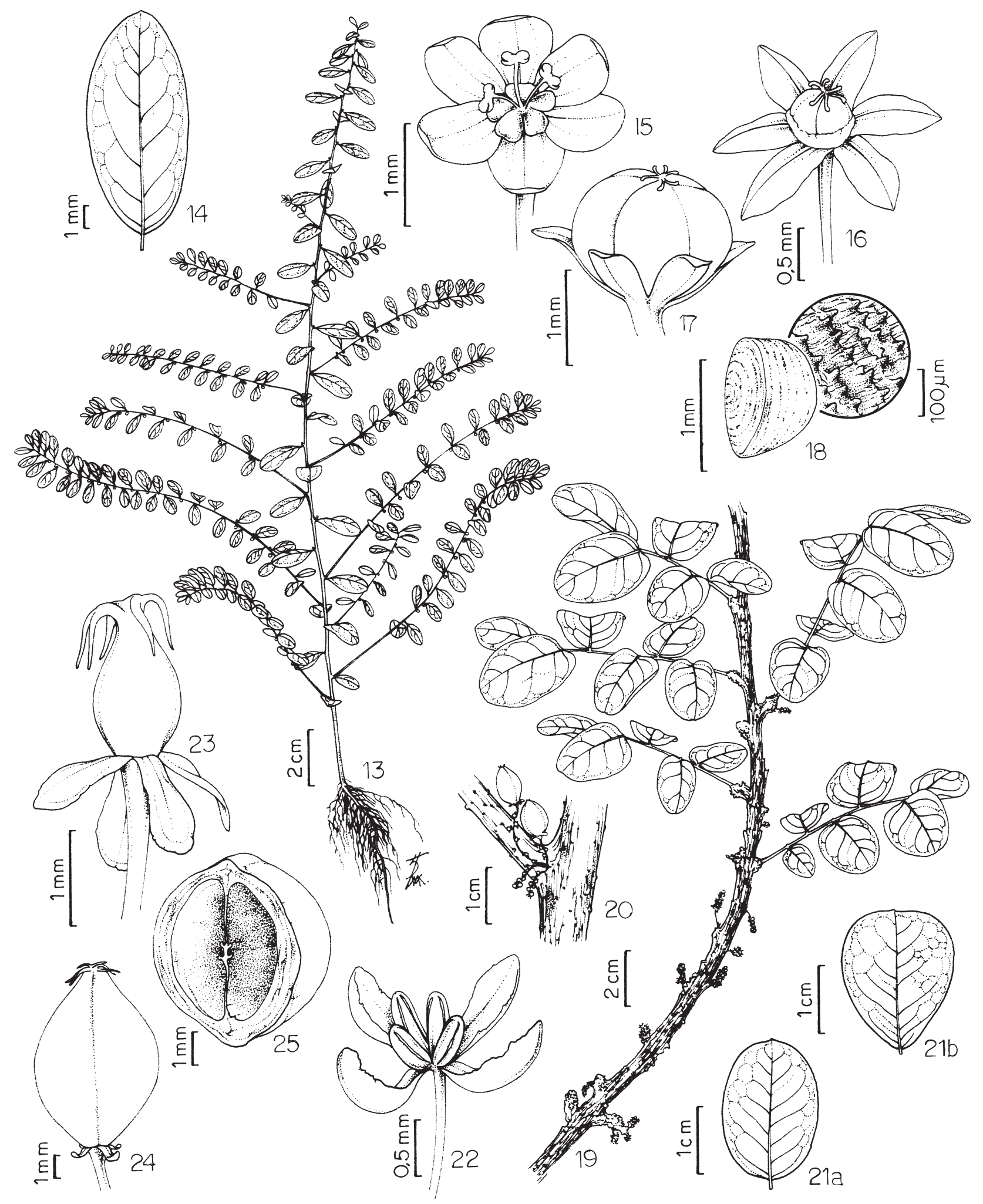

Figuras 13-18. Phyllanthus caroliniensis Walt. subsp. caroliniensis 13. Hábito. 14. Folha. 15. Flor estaminada. 16. Flor pistilada. 17. Fruto. 18. Aspecto geral da semente e detalhe de sua ornamentação (Silva 108). Figuras 19-25. P. chacoensis Morong 19. Ramo fértil. 20. Detalhe de um ramo frutificado. 21. Variação do limbo foliar. 21 a Limbo oblongo. 21b. Limbo oboval. 22. Flor estaminada. 23. Flor pistilada. 24. Fruto. 25. Fruto em seção transversal (Fotius 3652). 
este se diferencie pelo número de sépalas de ambas as flores e dos segmentos do disco glandular estaminado, e por ocorrer apenas em ambientes florestais. Floresce e frutifica entre maio e julho.

Phyllanthus gradyi M.J. Silva \& M.F. Sales, Novon 16:. 2006

Fig. 32-37

Árvore 3-6 m, monóica. Ramificação não filantóide; ramos cilíndricos, flexuosos a eretos, cinéreos, densamente tomentoso-ferrugíneos nas partes jovens. Estípulas 2-2,8 $\mathrm{mm}$, lanceoladas, acuminadas, densamente pubescentes. Pecíolo 1,5-2,1 mm, hirsuto. Limbo foliar 3,8-8 $\times 1,5-3,3 \mathrm{~cm}$, cartáceo, elíptico, base obtusa, ápice agudo e mucronulado. Fascículos estaminados com 6-13 flores, adensados no ápice dos ramos ou bissexuais com 2-3 flores cada, com (1) a 2 estaminadas e 1 pistilada; brácteas triangulares, pubescentes externamente. Flores estaminadas: pedicelo 0,7-1,1 cm, filiforme; sépalas 4 , ovais, ápice agudo a obtuso; disco cupuliforme com margem tetragonal; estames 2, livres, voltados um para o outro, filetes espessos, anteras com tecas divergentes, rimosas horizontalmente. Flores pistiladas: pedicelo, $1,2-3 \mathrm{~cm}$, filiforme, puberulento; sépalas 6, oblongo-lanceoladas, ápice arredonda; disco cupuliforme, margem discretamente lobada; ovário oblato; estiletes 3, bipartidos, patentes; estigmas agudos. Faixa central presente nas sépalas de ambas as flores. Cápsula 3,9-4×5-5,2 mm, oblata. Sementes 3-3,1 $\times 2,5-2,8 \mathrm{~mm}$, irregularmente trígonas, hilo obtriangular; testa areolada, castanho-claro, lustrosas.

Material examinado selecionado: BRASIL. Pernambuco: Abreu e Lima, 15/XI/2004, fl. fr., Silva, 556 (PEUFR, IPA, INPA); Barreiros, 27/IX/2004, fl. fr., Silva 542 (PEUFR); Caruaru, 11/II/1995, fl. fr., Mayo 1002 (PEUFR); Igarassu, 28/IX/2003, fl., Silva 305 (PEUFR); Recife, 7/III/1950, fl., Andrade-Lima 50-454 (IPA); São Lourenço da Mata, III/1953, fl, Pickel 11 (IPA); São Vicente Férrer, 29/I/1999, fl., Ferraz et al. 598 (PEUFR); Tamandaré, 13/I/2000, fl. fr., Lucena 811 (PEUFR).

Phyllanthus grandyi apresenta distribuição restrita à região Nordeste do Brasil, nas florestas atlântica (Pernambuco e Alagoas) e Montanas ("brejos" dos Cavalos, Caruaru, PE), em altitudes de 800-900 m, formando pequenas populações no interior da floresta, em ambientes úmidos. Distingue-se das demais espécies de Phyllanthus por apresentar ramificação não filantóide, cálice estaminado com quatro sépalas, dois estames livres com anteras rimosas horizontalmente, disco estaminado inteiro, flores pistiladas com seis sépalas e disco cupuliforme. Assemelha-se com P. biantherifer Croizat (amazônica) por ambas serem de ambiente florestal, possuírem o mesmo tipo de ramificação, número de sépalas estaminadas (quatro) e de estames (dois), bem como folhas cartáceas, elípticas e acuminadas. Entretanto, Phyllanthus grandyi difere de $P$. biantherifer por possuir estames livres, disco estaminado inteiro, ramos jovens densamente tomentosos e estípulas lanceoladas e com tricomas ferrugíneos externamente (vs. estames unidos, disco glandular segmentado, ramos glabros e estípulas triangulares e glabras, em $P$. biantherifer). Floresce e frutifica de outubro a março.

Phyllanthus heteradenius Müll. Arg., in Mart, Fl. bras. 11(2) 63. 1873.

Fig. 38-44

Erva 8,5-15,5 cm, anual. Caule ramificado ou não. Ramificação não filantóide. Ramos 3-7,5 mm, persistentes, com flores estaminadas ou pistiladas. Catafilos ausentes. Estípulas 0,8-1 mm, ovais, laceradas. Pecíolo 0,6-1,1 mm. Limbo foliar 4-11×3-6 mm, membranáceo, largamente elíptico a orbicular, base aguda a obtusa, ápice agudo a arredondado. Címulas estaminadas 2-4 flores, címulas pistiladas unifloras, ambas dispostas ao longo ou na inserção dos ramos; brácteas triangulares. Flores estaminadas: pedicelo $0,6-0,7 \mathrm{~mm}$; sépalas 5 , obovais, ápice cuspidado; disco com 5 segmentos, elípticos, caudados ou falcados; estames 3 , livres, anteras com rimas horizontais. Flores pistiladas: pedicelo 1,4-2 mm; sépalas 5 , obtruladas a obovais, cartáceas, verdeescuras; disco com 5 segmentos ovais; ovário oblato; estiletes livres, bífidos; estigma capitado. Cápsula 2,1-2,4 mm diâm., depresso-ovóide. Sementes 1-1,2× 0,9-1 mm, trígonas; hilo obtriangular, terminal; testa reticulado-punctada com 7-10 estrias esparsamente punctadas na face dorsal e 4-6 semiconcêntricas na dorsal, castanho a escuras a negras, lustrosas.

Material examinado selecionado: BRASIL. Pernambuco: Afrânio, 19/IV/1971, fl. fr., Heringer et al. 155 (IPA); Alagoinha, 9/IV/2001, fl. fr., Silva 165 (PEUFR); Betânia, 25/VIII/2001, fl. fr., Silva 127 (PEUFR); Brejo da madre de Deus, 14/II/2004, fl. fr., Silva 383 (PEUFR); Caruaru, 12/III/2004, fl. fr., Silva 395 (PEUFR); Serra Talhada, 5/II/1998, fl., Laurênio et al. 735 (PEUFR).

Espécie endêmica do Brasil nas regiões Nordeste (PB, PE, AL, SE, BA, RN) e Sudeste (MG), em 


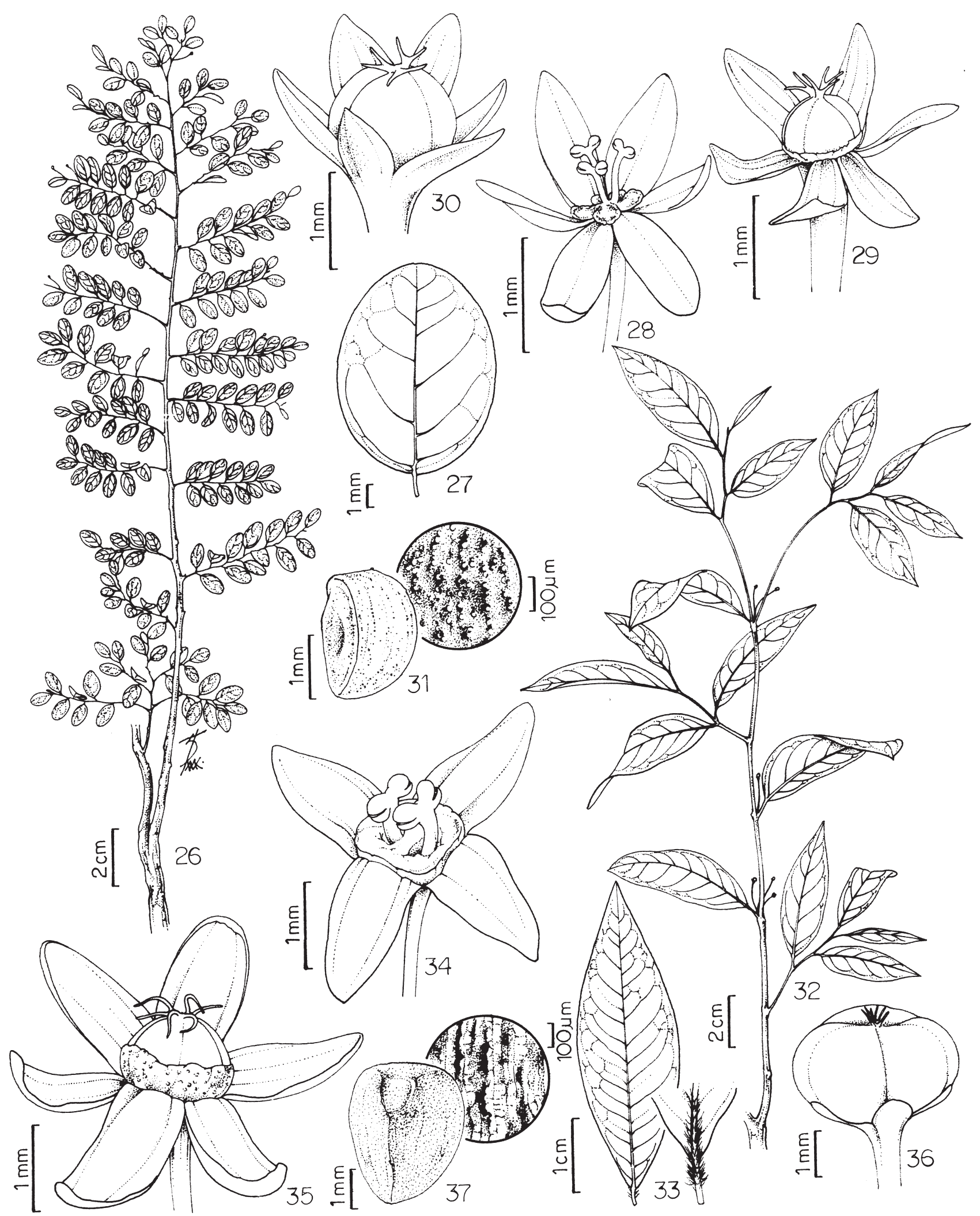

Figuras 26-31. P. claussenii Müll. Arg. 26. Ramo florido. 27. Folha. 28. Flor estaminada. 29. Flor pistilada. 30. Fruto. 31. Aspecto geral da semente e detalhe de sua ornamentação (Silva 450). Figuras 32-37. Phyllanthus gradyi M.J. Silva \& M.F. Sales. 32 . Ramo florido. 33. Folha, aspecto geral e detalhe de sua base. 34. Flor estaminada. 35. Flor pistilada. 36. Fruto. 37. Aspecto geral da semente e detalhe de sua ornamentação (Silva 556). 




Figuras 38-44. P. heteradenius Müll. Arg. 38. Hábito. 39. Folha. 40. Flor estaminada. 41. Disco glandular estaminado, detalhe. 42. Flor pistilada. 43. Fruto. 44. Aspecto geral da semente e detalhe de sua ornamentação (Silva 383). Figuras 45-50. P. hypoleucus Müll. Arg. 45. Hábito. 46. Folha. 47. Flor estaminada. 48. Flor pistilada. 49. Fruto. 50. Aspecto geral da semente e detalhe de sua ornamentação (Silva 208). 
ambientes de caatinga e dunas litorâneas. Neste estudo foi verificada apenas em vegetação de caatinga, ocorrendo desde a subzona do Agreste (Caruaru) até a do Sertão (Floresta, Petrolina, Betânia, Alagoinha), em locais abertos, pouco úmidos, sob a sombra de outras plantas. É reconhecida pelas flores pistiladas com sépalas cartáceas, disco glandular estaminado com segmentos elípticos e caudados ou falcados, disco pistilado parcialmente unido na base, com segmentos largamente ovais, além de sementes reticuladopunctadas. Tais características a diferenciam das demais, especialmente de $P$. caroliniensis subsp. caroliniensis, com o qual mais se assemelha. Floresce e frutifica de fevereiro a agosto.

Phyllanthus hypoleucus Müll. Arg., Linnaea 32: 40. 1863.

Fig. 45-50

Subarbusto 12-32 cm, perene. Ramificação filantóide. Catafilos 1,3-1,4 mm, triangulares, acuminados. Ramos decíduos, 4-11,3 cm, pinatiformes, cilíndricos e com emergências papilosas. Estípulas 1,1-2,1 mm, triangulares. Pecíolo 1,1-1,8 mm. Limbo foliar 1,9-5,5×1-2,9 cm, membranáceo, elíptico a elíptico-oboval, base oblíqua, ápice arredondado a agudo, minutamente papilosa em ambas as faces. Címulas bissexuais, axilares, constituídas por uma flor pistilada e 2-3 flores estaminadas. Brácteas ovais. Flores estaminadas: pedicelo 0,9-1,4 cm, filiforme; sépalas 5, largamente elípticas a obovais, ápice agudo; disco com 5 segmentos obtriangulares, papilosos; estames 3, livres, anteras com rimas horizontais. Flores pistiladas: pedicelo 1,8-3 cm, filiforme; sépalas 5 , obovais a largamente obtruladas; ápice agudo; faixa central presente; disco cupuliforme; ovário depresso-oval; estiletes livres, bipartidos; estigmas capitados. Cápsula 1,6-1,7×3-3,1 mm, depresso-oval. Sementes 1,7-1,8×1,5-1,6 mm, trígonas; hilo obtriangular, terminal; testa com pontuações ligeiramente elevadas, arranjadas longitudinalmente na face dorsal e semiconcêntricamente nas faces laterais, castanhoclaro, lustrosas.

Material examinado: BRASIL. Pernambuco: Vicência, 26/VIII/2002, fl. fr., Silva 201 (PEUFR); Nazaré da Mata, 20/I/1955, fl. fr., Moraes s.n. (EAN 1382); Aliança, 24/V/2005, fl., Lopes et al. 375 (PEUFR).

Espécie com distribuição no Brasil (BA, PE e ES), crescendo na floresta atlântica, desde o nível do mar até 1.000 m, no Espírito Santo, (Webster 2002b). Em
Pernambuco ocorre na Floresta Atlântica, no interior de matas secundárias. Distingue-se das demais espécies pelo hábito subarbustivo, ramos e ambas as faces das folhas com emergências, flores pistiladas e estaminadas com pedicelo longo $(1,8-3 \mathrm{~cm}$, nas pistiladas e 0,9-1,4 $\mathrm{cm}$ nas estaminadas), filiforme e frutos verde-claros a esbranquiçados. Assemelha-se morfologicamente a $P$. niruri por compartilhar a assimetria da base das folhas, o tipo de ramificação (filantóide), a forma dos segmentos do disco estaminado e o número de estames (três).

Phyllanthus juglandifolius Willd., Enum. Hort. Berol. Suppl. 64-65. 1813.

Fig. 51-57

Árvore 6-7 m. Ramificação filantóide; ramos 23-33 cm, pinatiformes, em geral agrupados no ápice, subcilíndricos, pubescentes nas partes jovens, fistulosos. Catafilos 1,3-1,6 mm, rígidos. Estípulas ca.1,5 mm, lanceoladas. Pecíolo 2-3,2 mm. Limbo foliar 4,5-8,5×2-3 cm, cartáceo, oblongo a ovaloblongo, raro elíptico, base obtusa, ápice acuminado. Tirsos bissexuais com 2-4 flores estaminadas e 3-7 flores pistiladas, dispostas na porção proximal dos ramos; pedúnculo ca. $2 \mathrm{~mm}$; brácteas lanceoladas. Flores estaminadas: pedicelo 1,2-1,5 cm, filiforme; sépalas 5, elípticas a oblongas; disco inteiro, superfície foveolada; estames 4 a 6 , unidos; anteras cordiformes, deiscência sub-horizontal. Flores pistiladas: pedicelo 1,3-1,8 cm, subcilíndrico; sépalas 5, oblongo-obovais a elípticas, venuladas; disco inteiro; ovário subgloboso; estiletes unidos, bífidos ou emarginados; estigmas arredondados. Cápsula 4-5×12-15 mm, oblata, profundamente sulcada entre as cocas. Sementes 5,1-6,7×4-5 mm, reniformes; hilo linear a oblongo na porção mediana ou central; testa lisa, castanho-claro a negras.

Material examinado: BRASIL. Pernambuco: São Lourenço da Mata, 17/V/2001, fl. fr., Silva 60 (PEUFR); Recife, 13/III/1951, fl. fr., AndradeLima 906 (IPA); Bonança, s.d., fl. fr., Pickel 1275 (IPA).

Distribuição na América do Sul (Bolívia, Brasil, Equador, Guiana Francesa, Peru, Trinidad e Tobago e Venezuela) e América Central (Antilhas), ocorrendo em florestas secundárias (Webster 1956). No Brasil, ocorre nas regiões Norte (PA, RO), Nordeste (BA, MA, PB, PE) e Sudeste (MG, RJ), na floresta atlântica (borda ou interior da mata), próximo a ambientes alagadiços e rochosos; em Pernambuco, restringe-se à zona da Mata, crescendo na borda das florestas. 




Figuras 51-57. Phyllanthus juglandifolius Wild. 51. Ramo florido. 52. Detalhe do ramo frutificado. 53. Folha. 54. Flor estaminada. 55. Flor pistilada. 56. Fruto. 57. Aspecto geral da semente (Silva 60). Figuras 58-63. P. klotzschianus Müll. Arg. 58. Ramo, aspecto geral. 59. Ramo fértil, aspecto. 60. Flor estaminada. 61. Flor pistilada. 62. fruto. 63. Aspecto geral da semente e detalhe de sua ornamentação (Silva 502). 
Distingue-se pelo hábito arbóreo, caule pouco ramificado, com os ramos agrupados ao ápice, frutos oblatos e sementes reniformes. É conhecida popularmente como "cajazeira braba" e "carobinha", em Pernambuco e na Bahia. Floresce e frutifica nos meses de fevereiro, março e maio.

Phyllanthus klotzschianus Müll. Arg., Linnaea 32: 53. 1863.

Fig. 58-63

Subarbusto ou arbusto 0,5-1,8 m. Ramificação filantóide; ramos secundários e terciários modificados em cladódios; cladódios 4,5-14,1×0,3-0,7 cm, coriáceos, laminares, lanceolados a lineares, base atenuada, ápice obtuso a falcado, verde-escuros, lustrosos. Folhas presentes nas plantas jovens; Pecíolo ca. $1 \mathrm{~mm}$. Limbo foliar oboval a elíptico-oboval 5-11×3-7 mm, ápice agudo a obtuso, base obtusa. Catafilos 2-4 mm, triangulares ou lanceolados, coriáceos. Címulas estaminadas 2-3 flores, flores pistiladas em geral solitárias, ambas dispostas nas margens dos cladódios; brácteas triangulares. Flores estaminadas sésseis; sépalas 5 , oblongo-obovais a largamente obovais, subcoriáceas, discretamente venadas; disco com cinco segmentos pateliformes; estames 3, unidos; anteras assimétricas, rimas verticais a oblíquas. Flores pistiladas sésseis; sépalas 5 , semelhantes as estaminadas; disco levemente cupuliforme; ovário depresso-oval; estiletes livres, eretos, bífidos; estigmas obtusos. Cápsula 3-3,5×3-4,5 mm, oblata. Sementes 1,3-2×2-2 mm, trígonas; hilo obtriangular, terminal; testa reticulada, castanho-escuras.

Material examinado: BRASIL. Pernambuco: Afrânio, 24/IV/1971, fl. fr., Heringer et al s.n. (IPA); Buíque, 9/IX/2004, fl., Silva 502 (PEUFR); Garanhuns, 26/I/1977, fl., Pontual 77 (PEUFR).

Distribuição exclusiva no Brasil (AL, BA, ES, GO, MG, PE, RJ, SE, SP) em cerrado, campo rupestre, carrasco, caatinga e restinga, crescendo em ambientes abertos, rochosos ou em solos arenosos e arenopedregosos. Em Pernambuco ocorre no semi-árido, associada a ambiente rupestre, em fendas de rochas de arenito ou em paredões de $6 \mathrm{~m}$ de altura, onde apresenta maior porte $(1,80 \mathrm{~m})$. Distingue-se por apresentar cladódios, segmentos do disco estaminado patelifomes e sementes reticuladas. Assemelha-se morfologicamente a P. angustissimus Müll. Arg. (BA e MG), diferindo pelas flores sésseis (vs. pediceladas em $P$. angustissimus), tecas assimétricas (vs. simétricas) e ramos dos estiletes eretos (vs. reflexos). Floresce e frutifica de janeiro a outubro.
Phyllanthus minutulus Müll. Arg. in Mart., Fl. bras. 11(2): 54. 1874.

Fig. 64-69

Erva 5,5-20 cm, anual. Ramificação filantóide; ramos 1,1-2,1 cm, pinatiformes, angulosos. Catafilos ca. 0,6 mm, lanceolados. Estípulas ca. 0,7 mm, lanceoladas. Pecíolo ca. 0,4 mm. Limbo foliar 2,6-5,1× 1,4-2 mm, membranáceo, oval a oval-elíptico, base arredondada, ápice obtuso. Címulas unissexuais estaminadas com 2-3 flores, dispostas na porção proximal dos ramos; brácteas triangulares. Flores estaminadas: pedicelo ca. $0.4 \mathrm{~mm}$; sépalas 5, obovais, ápice arredondado e mucronulado; disco com 5 segmentos clavados; estames 2, unidos, anteras com rimas horizontais. Flores pistiladas solitárias na porção distal dos ramos; brácteas triangulares; pedicelo ca. $1 \mathrm{~mm}$, cilíndrico; sépalas 5 , obovais, ápice arredondado; faixa central presente; disco cupuliforme; ovário depresso-oval; estiletes livres, bífidos; estigma levemente bilobado. Cápsula ca. $1 \times 1,8 \mathrm{~mm}$, oblata. Sementes ca. $1 \times 0,9-1 \mathrm{~mm}$, trígonas, hilo terminal, obtriangular; testa com 5-6 fileiras de estrias transversais arranjadas longitudinalmente no dorso e com 3-4 arranjadas semiconcêntricamente nas faces laterais, castanho-escuras.

Material examinado: BRASIL. Pernambuco: Barreiros, 27/IX/2004, fl. fr., Silva 536 (PEUFR); Goiana, 1/V/1936, fl. fr., Mello s.n. (4144 IPA); Igarassu, 11/VII/2003 fl. fr., Silva 371 (PEUFR).

Distribuição na América do Sul (Brasil, Colômbia, Guiana e Venezuela) (Webster 1956; 2002b). No Brasil ocorre de norte a sul, nos domínios amazônico, atlântico e do cerrado, nas florestas e em matas de galeria. Em Pernambuco, está restrita às zonas do Litoral e Mata, crescendo na restinga, em locais abertos e solos arenosos e na floresta atlântica, na borda da mata, em locais sombreados e úmidos. As flores estaminadas com dois estames unidos, as sépalas obovais, os segmentos do disco clavados e as folhas oval-elípticas, a distinguem das demais espécies. Assemelha-se a P. stipulatus com a qual compartilha o tipo de ramificação e o número de sépalas em ambas as flores, embora diferencie pelos dois estames (vs. três em P. stipulatus), flores pistiladas com pedicelo 1-1,1 mm (vs. 1,7-1,8 mm) e folhas ovais a elípticas (vs. oblongas). Floresce e frutifica de maio a agosto.

Phyllanthus niruri L., Sp. pl. 2: 981-982. 1753. Fig. 70-76

Erva ou subarbusto $12-73 \mathrm{~cm}$, anual. Ramificação filantóide; ramos 3-15,5 cm, angulosos. Catafilos 


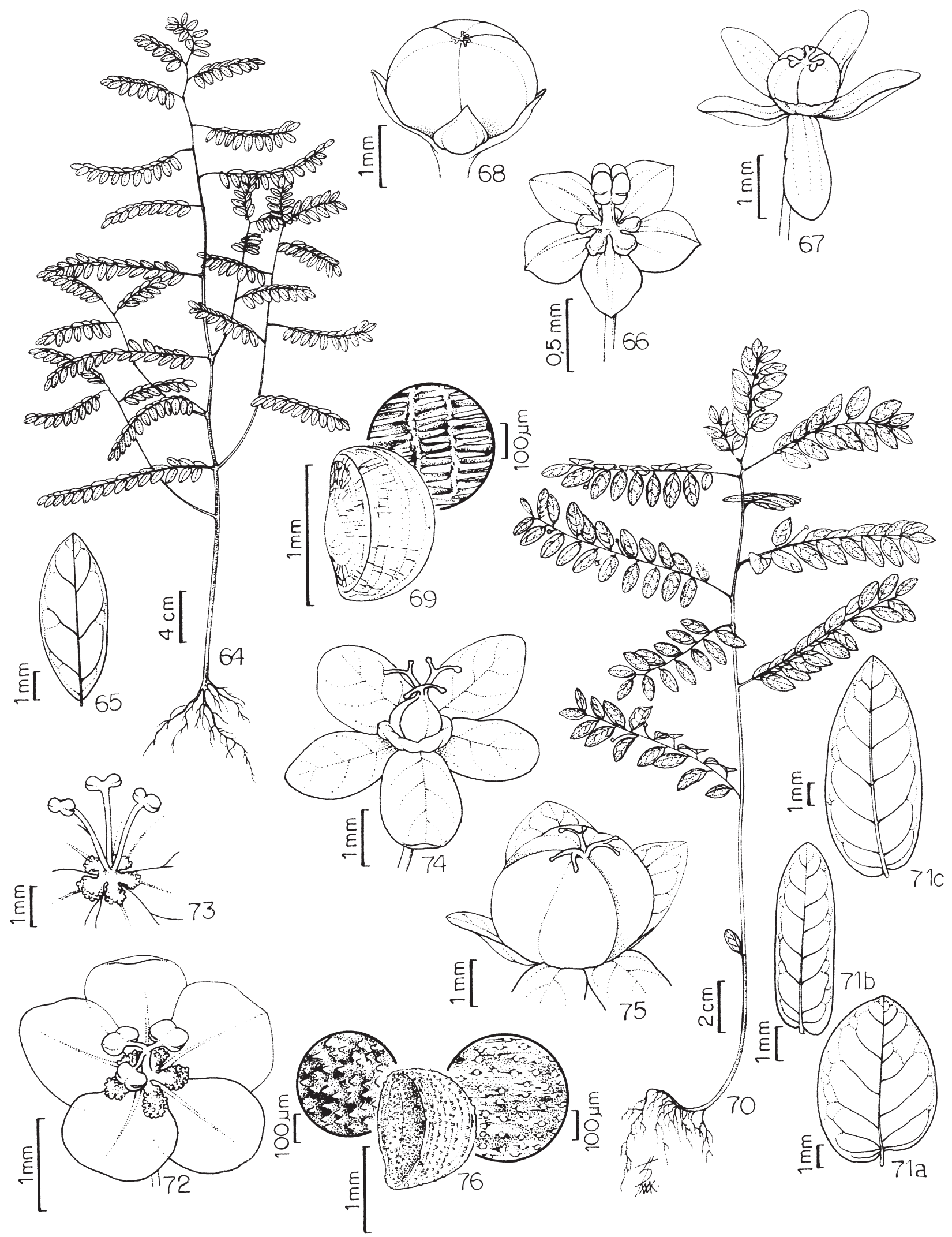

Figuras 64-69. Phyllanthus minutulus Müll. Arg. 64. Hábito. 65. Folha. 66. Flor estaminada. 67. Flor pistilada. 68. Fruto. 69. Aspecto geral da semente e detalhe de sua ornamentação (Silva 536). Figuras 70-76. P. niruri L. 70. Hábito. 71. Variação do limbo foliar. 71a. Limbo oval. 71b. Limbo oblongo. 71c. Limbo elíptico. 72. Flor estaminada. 73. Detalhe do androceu com estames livres. 74 . Flor pistilada. 75. Fruto. 76. Aspecto geral da semente e detalhe de sua ornamentação (Silva 343). 
1-1,3 mm, lanceolados, membranáceos. Estípulas 1,5-2,9 mm. Pecíolo 0,4-0,8 mm. Limbo foliar 5-15× 2,5-6 mm, membranáceo, oblongo a oblongo-elíptico, oval-oblongo ou oval-elíptico, base oblíqua, ápice obtuso a arredondado. Címulas estaminadas com 2-4 flores na porção proximal dos ramos; brácteas lineares a lanceoladas. Flores estaminadas: pedicelo 1,9-2,5 mm; sépalas 5, obovais a largamente obovais, ápice arredondado, côncavas; disco com cinco segmentos obtriangulares ou trapezoidais com papilas; estames 3 , livres a parcialmente unidos; anteras com rimas horizontais a oblíquas. Flores pistiladas solitárias nas terminações dos ramos; brácteas lineares; pedicelo 3-3,8 mm, subcilíndrico; sépalas 5, largamente elípticas, obovais a largamente obovais, côncavas; disco anular; ovário depresso-oval; estiletes livres, bífidos; estigmas capitados. Cápsula 1,2-2×2-2,1 mm, subglobosa. Sementes 1-1,6×1-1,3 mm, trígonas; hilo obtriangular; testa com verrugas alinhadas longitudinalmente na face dorsal e semiconcêntricas nas faces laterais, castanhoclaro, lustrosa.

Material selecionado: BRASIL. Pernambuco: Betânia, 1/VI/2002, fl., Fernandes 62 (PEUFR); Bonito, 1/VIII/2001, fl. fr., Silva 109 (PEUFR); Brejo da Madre de Deus, 5/II/1999, fl. fr., Krause \& Liebig 112 (PEUFR); Caruaru, 25/VII/2001, fl. fr., Silva 103 (PEUFR); Floresta, 20/VII/1995, fl. fr., Sales \& Rodal 644 (PEUFR); Glória do Goitá, 10/VII/2004, fl. fr., Silva 465 (PEUFR); Ouricuri, 4/V/1971, fl., Heringer et al. 480 (PEUFR); Pesqueira, 2/VII/2004, fl. fr., Silva 451 (PEUFR); São Vicente Férrer, 14/VI/2003, fl. fr., Silva 344 (PEUFR); São Lourenço da Mata, Pickel 289 (SP); Taquaritinga do Norte, 16/IV/2005, fl., Silva et al. 626 (PEUFR).

Distribuição do Sul do Texas (Estados Unidos) à Argentina, incluindo Antilhas (Webster 1970). No Brasil ocorre em todas as regiões, em diferentes tipos vegetacionais, em locais úmidos e sombreados ou em áreas ruderais. Em Pernambuco ocorre desde a zona litorânea até a semi-árida. Assemelha-se com P. hypoleucus pela assimetria das folhas, número de estames (três), deiscência das anteras (horizontal) e tipo de ramificação (filantóide). No entanto, $P$. hypoleucus diferencia pelos ramos e ambas as faces das folhas com emergências papilosas. É conhecida popularmente como "quebra-pedra" e "ervapombinha". Floresce e frutifica todo ano.

Phyllanthus orbiculatus L.C. Rich., Act. Soc. Hist. Nat. Paris 1: 113. 1792.

Fig. $77-82$
Erva 7,5-14 cm, anual. Ramificação filantóide; ramos $3-10 \mathrm{~cm}$, pinatiformes, angulosos. Catafilos ca. $1 \mathrm{~mm}$, triangulares. Estípulas ca. 0,9 mm, triangulares. Pecíolo ca. 0,5 mm. Limbo foliar 8-11× 8-10 mm, membranáceo, orbicular a largamente orbicular, base arredondada, ápice arredondado, às vezes ligeiramente mucronulado. Inflorescência bissexual, curto pedunculada, com duas címulas estaminadas laterais e uma flor pistilada central longo pedunculada; címulas estaminadas com 3-4-floras; brácteas triangulares. Flores estaminadas: pedicelo 2,3-4 mm, filiforme; sépalas 6, elípticas a oval-elípticas; disco com seis segmentos obtriangulares e discretamente papilosos; estames 3, livres, anteras com rimas horizontais. Flores pistiladas: pedicelo ca. $3 \mathrm{~mm}$, filiforme; sépalas 6 , oblongas a lineares, faixa central presente; ápice agudo; disco pateliforme; ovário globoso; estiletes livres, bífidos, recurvados; estigmas subcapitados. Cápsula ca. 2×2-2,1 mm, depresso-oval. Sementes 1,1-1,2×1-1,1 mm, trígonas; hilo obtriangular, terminal; testa com verruculas arranjadas em 12-13 fileiras longitudinais na face dorsal e 8-10 semiconcêntricas em cada uma das laterais, castanho-clara, lustrosa.

Material examinado: BRASIL. Pernambuco: São Lourenço da Mata, 30/XI/2002, fl. fr., Silva 300 (PEUFR); Cabo, 17/IX/1999, fl. fr., Júnior 50 (PEUFR); Glória do Goitá, 10/VII/2004, fl. fr., Silva 478 (PEUFR);Paulista, 12/V/2003, bot., Silva 320 (PEUFR).

Espécie de distribuição ampla na América do Sul (Brasil, Bolívia, Paraguai, Colômbia, Venezuela, Guianas e Peru) (Webster 1956), alcançando ainda as pequenas Antilhas (Trinidad e Tobago), na América Central. No Brasil ocorre da região Norte (AM, RR) a sudeste (AL, BA, CE, GO, MT, MS, MG, PI, SP); em Pernambuco, apenas nas zonas do Litoral e da Mata, em bordas ou interior das florestas Diferenciase das demais estudadas pelo hábito herbáceo delicado, folhas orbiculares a largamente orbiculares, inflorescência cimosa bissexual, além de sépalas estaminadas e pistiladas em número de seis.

Phyllanthus stipulatus (Raf.) Webster, Contr. Gray. Her. 176: 53. 1955.

Fig. $83-88$

Erva 30-45 cm, ereta, anual. Ramificação filantóide; caule cilíndrico, aerênquima esbranquiçado na porção basal, em indivíduos de locais paludosos; ramos 3-8 cm, pinatiformes, Catafilos 1-2 mm, triangulares, acuminados. Estípulas 1-1,2 mm, lanceoladas. Pecíolo 0,5-0,8 mm. Limbo foliar 7-10× 


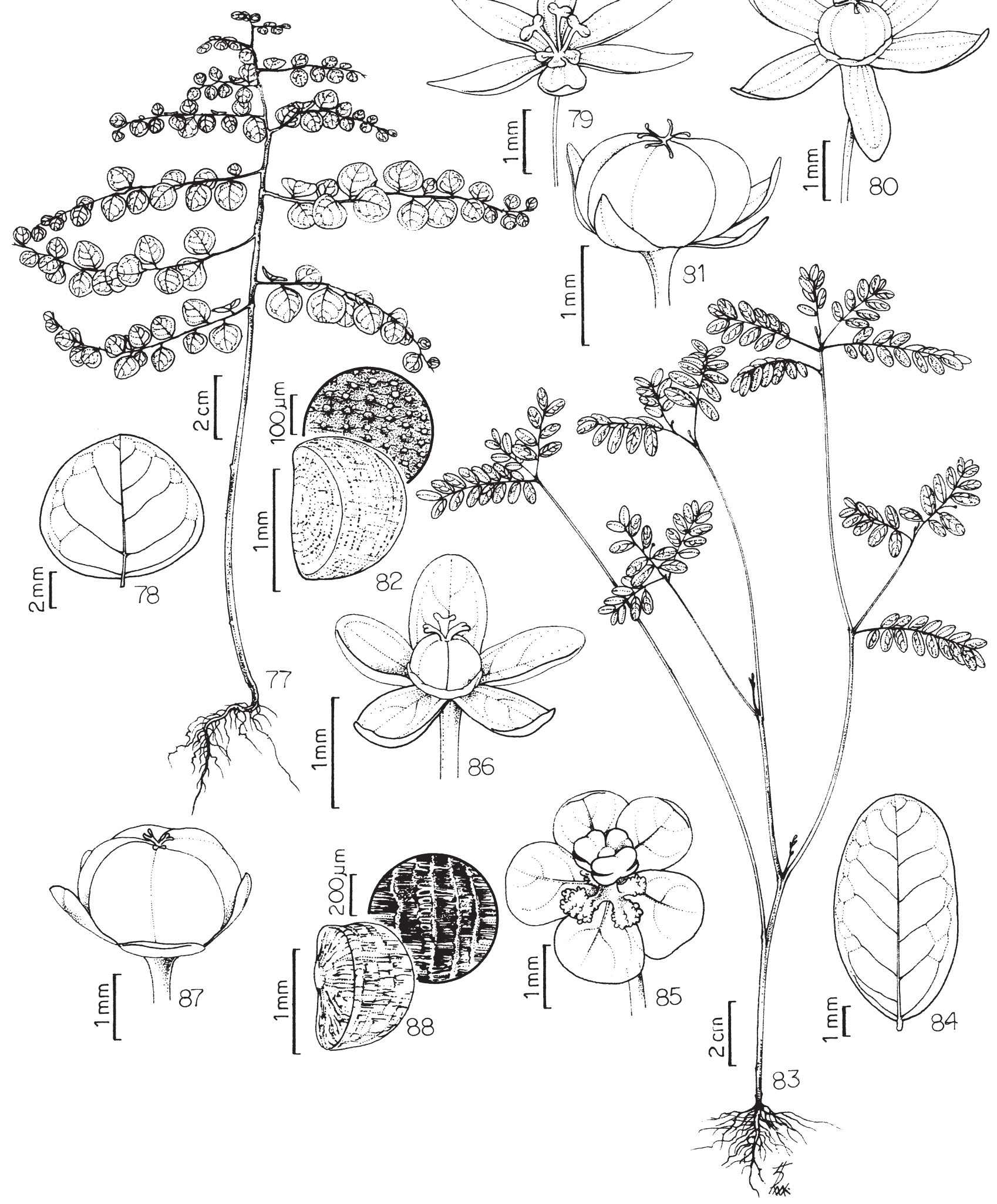

Figuras 77-82. Phyllanthus orbiculatus L.C. Rich. 77. Hábito. 78. Folha. 79. Flor estaminada. 80. Flor pistilada. 81. Fruto. 82. Aspecto geral da semente e detalhe de sua ornamentação (Silva 111). Figuras 83-88. P. stipulatus (Raf.) Webster. 83. Hábito. 84. Folha. 85. Flor estaminada. 86. Flor pistilada. 87. Fruto. 88. Aspecto geral da semente e detalhe de sua ornamentação (Silva 572). 
2,1-4,8 mm, membranáceo, oblongo a oblongo-elíptico, base aguda, ápice arredondado. Címulas unissexuais estaminadas 3-4(-5) flores, na porção proximal dos ramos, flores pistiladas solitárias na porção terminal dos ramos; brácteas lineares. Flores estaminadas: pedicelo 0,8-1 mm, cilíndrico; sépalas 5, com 0,8-1,3 mm, obovais, ápice arredondado; disco com cinco segmentos arredondados e verruculosos; estames 3, unidos; anteras com rimas horizontais. Flores pistiladas: pedicelo 1,7-1,8 mm, subcilíndrico; sépalas 5, com 1,5$1,8 \mathrm{~mm}$, obovais, faixa central presente; ápice arredondado; disco cupuliforme; ovário depresso-oval; estiletes livres, bífidos, ascendentes e recurvados; estigmas subcaptados. Cápsula 1,6-1,8×2-2,1 mm, depresso-oval. Sementes ca. $1,1 \mathrm{~mm}$, trígonas; hilo obtriangular, terminal; testa com 10-12 fileiras de estrias transversais dispostas em fileiras longitudinais no dorso, 4-5 semiconcêntricas em cada face lateral, castanhoclara a escura.

Material examinado selecionado: BRASIL. Pernambuco: Belém de Maria, 4/VI/2003, fl. fr., Silva 339 (PEUFR); Bonito, 1/VIII/2001, fl. fr., Silva 111 (PEUFR); Brejo da Madre de Deus, 14/II/2004, fl. fr., Silva 384 (PEUFR); Cabo, 17/IX/1999, fl. fr., Paiva 50 (PEUFR); Caruaru, 5/X/2001, fl. fr., Silva 133 (PEUFR); Maraial, 13/VI/2003, fl. fr., Silva 323 (PEUFR).

Ocorre desde o sudeste dos Estados Unidos, abrangendo as Antilhas, até o sul do Brasil, especialmente em locais paludosos de ambientes florestais (Webster 1970; 2002b). No Brasil, é encontrada de Norte a Sul, em florestas e cerrados; em Pernambuco, nas florestas de terras baixas e Montanas, em locais sombreados e paludosos. A presença de aerênquima na base do caule, associada às folhas oblongo-obovais, ao disco estaminado com segmentos circulares e verruculosos e aos estames unidos em coluna, a distinguem das demais espécies. Compartilha $\operatorname{com} P$. amarus o limbo foliar oblongo, o tipo de ornamentação das sementes (estriado), o mesmo número de estames (três), mas diferencia pelas anteras não oblíquas e címulas bissexuais (vs. anteras com rimas horizontais e címulas unissexuais). Floresce e frutifica em todo ano

Phyllanthus subemarginatus Müll. Arg., Linnaea 32:39. 1863.

Fig. 89-94

Subarbusto 48-80 cm, cespitoso. Ramificação não filantóide; ramos pinatiformes, às vezes ligeiramente dispostos em zigue-zague, angulosos. Catafilos ausentes. Estípulas 1-1,3 mm, oval-triangulares, margem levemente denticulada. Pecíolo 1,2-2 mm. Limbo foliar 12-19×9-12 mm, membranáceo, largamente elíptico a orbicular, base obtusa, ápice arredondado e discretamente mucronulado. Címulas bissexuais, 1 flor pistilada com pedicelo articulado e (1-) 2 flores estaminadas dispostas ao longo dos ramos; brácteas triangulares. Flores estaminadas: pedicelo 2,3-3,5 mm, filiforme; sépalas 5, largamente obovais, ápice arredondado; disco com cinco segmentos obtriangulares e verruculosos; estames 3 , livres, anteras oblongas com rimas horizontais. Flores pistiladas: pedicelo 4-10,5 $\mathrm{mm}$, filiforme; sépalas 5, membranáceas, obtruladas, faixa central presente; disco pateliforme; ovário subgloboso; estiletes livres, bífidos; estigma subcapitado. Cápsula ca. $1,1 \mathrm{~mm}$ e 1,8-2 mm diâm., depresso-ovóide. Sementes ca.1mm, trígonas, hilo obtriangular, terminal; testa com diminutas mamilas arranjadas em 10-12 fileiras longitudinais na face dorsal e 4-5 semiconcêntricas nas faces laterais, castanho-claro, lustrosa.

Material examinado selecionado: BRASIL. Pernambuco: Bezerros, 17/VII/1999, fl. fr., Krause \& Liebig 67 (PEUFR); Caruaru 10/IV/2002, fl. fr., Silva 188 (PEUFR); Taquaritinga do Norte, 16/IV/2005, fl. fr., Silva et al. 643 (PEUFR).

Espécie restrita ao Brasil (BA, PE, RJ, SC, SP) crescendo ao longo da costa em ambientes florestais (florestas de terras baixas e montanas). Em Pernambuco ocorre nas florestas litorâneas montanas, em locais úmidos e sombreados. Na descrição original, Müller (1863) a referiu como dióica, provavelmente por ter se baseado em espécimes cujas flores pistiladas haviam caído. No entanto, a análise detalhada de materiais provenientes de diversas partes do país possibilitou constatar ser a espécie monóica. Pode ser reconhecida pelo hábito ereto ou cespitoso, pelas flores estaminadas e pistiladas com cinco sépalas e estames com tecas não divergentes. Tais características a diferenciam de $P$. claussenii, com a qual é facilmente confundida, embora esta última seja um arbusto densamente ramificado, com seis sépalas em ambas as flores e anteras com tecas estipitadas. Floresce e frutifica de abril a novembro.

Phyllanthus tenellus Roxb., Flora Indica 2(3): 668. 1882.

Fig. $95-100$

Erva 15-60 cm. Ramificação filantóide; ramos 4,5-8,5 cm, pinatiformes, vináceos, angulosos. Catafilos ca. $1 \mathrm{~mm}$ lanceolados. Estípulas ca. 1,2 mm, lanceoladas. 




Figuras 89-94. Phyllanthus subemarginatus Müll. Arg. 89. Hábito. 90. Folha. 91. Flor estaminada. 92. Flor pistilada. 93. Fruto. 94. Aspecto geral da semente e detalhe de sua ornamentação (Silva 188). Figuras 95-100. P. tenellus Roxb. 95. Hábito. 96. Folha. 97. Flor estaminada. 98. Flor pistilada. 99. Fruto. 100. Aspecto geral da semente e detalhe de sua ornamentação (Silva 560). Figuras 101-106. P. urinaria 101. Hábito. 102. Limbo foliar. 103. Flor estaminada. 104. Flor pistilada. 105. Fruto. 106. Aspecto geral da semente e detalhe de sua ornamentação (Silva 356). 
Pecíolo ca. $1 \mathrm{~mm}$. Limbo foliar 7-15×5-7 mm, membranáceo, elíptico a elíptico-oboval, base aguda, ápice obtuso. Címulas bissexuais com um ramo estaminado com 3(4) flores e com duas flores pistiladas visivelmente articuladas em suas laterais e címulas unissexuais pistiladas bifloras ou unifloras, as unifloras nas terminações dos ramos e as bifloras na porção intermediária dos mesmos, sendo estas articuladas; brácteas triangulares. Flores estaminadas: pedicelo 1-1,2 mm, cilíndrico; sépalas 5, elíptico-obovais ou largamente obovais, ápice arredondado; disco com cinco segmentos obtriangulares, lisos; estames 5, livres, encurvados, anteras com rimas suboblíquas. Flores pistiladas: pedicelo $(2,5) 5-6,5 \mathrm{~mm}$, filiforme, base espessada, articulado; sépalas 5, ovais, faixa central elíptica; disco pateliforme; ovário depresso-oval; estiletes livres, bífidos; estigmas subcapitados. Cápsula 1-1,1×1,9-2 mm, oblata. Sementes 0,9-1×0,8-0,9 mm, trígonas, hilo terminal, obtriangular; testa com células escamiformes alinhadas longitudinalmente no dorso e semiconcêntricamente nas faces laterais, castanho-escura.

Material examinado: BRASIL. Pernambuco: Caruaru, 5/X/2001, fr., Silva 138 (PEUFR); Camaragibe, 15/XI/2004, fl. fr., Silva 560 (PEUFR); Garanhuns, 19/XI/2004, fl. fr., Silva 584 (PEUFR); Jupí, 19/XI/2004, fl. fr., Silva 579 (PEUFR); Petrolina, 7/IX/2002, fl. fr., Silva 233 (PEUFR).

Espécie pantropical, com ampla distribuição nas Américas (sudeste dos Estados Unidos até a Argentina) (Webster 1956; 1970). No Brasil, ocorre da região Norte até a Sul (AM, DF, MG, PE, PR, RJ, RS, SC, SP) em diferentes ambientes: florestais, de cerrado (mata de galerias), de caatinga, e como invasoras de culturas e jardins e, ainda, ruderal. Em Pernambuco, distribui-se desde o litoral até a subzona do Sertão, em áreas cultivadas, terrenos baldios, canteiros de jardins e frestas de calçadas e, ainda, em áreas abertas da floresta atlântica (litorânea e montanas) e na caatinga. Distingue-se das demais espécies pelas flores pistiladas com pedicelo longo (5-6,5 mm), filiforme, articulado, com base alargada, androceu com cinco estames livres e anteras com rimas sub-horizontais. É conhecida popularmente como "quebra-pedra roxo" ou "erva-pombinha" (PE, BA e SC). Floresce e frutifica o ano inteiro.

Phyllanthus urinaria L., Sp. pl. 1: 982. 1753.

Fig. 101-106

Erva $15-70 \mathrm{~cm}$, anual. Ramificação filantóide; ramos 4,5-8,5 cm, pinatiformes, angulosos, discretamente alados, levemente híspidos, oliváceos. Catafilos ca. $1 \mathrm{~mm}$, triangulares, acuminados, discretamente auriculados. Estípulas ca.1,6 mm, triangulares. Pecíolo ca. $0,7 \mathrm{~mm}$. Limbo foliar 10-14 ×2,8-3,8 mm, membranáceo, oblongo a oblongo-espatulado, base assimétrica, ápice arredondado, margem hispídula basalmente. Címulas unissexuais estaminadas, com 2-3 flores dispostas na porção distal dos ramos; brácteas triangulares. Flores estaminadas subsésseis; sépalas 6, elípticas a elíptico-oboval, ápice arredondado, margem erosa; disco com seis segmentos subglobosos, verruculosos; estames 3, unidos, anteras com rimas verticais. Flores pistiladas solitárias, axilares, dispostas na porção proximal dos ramos, subsésseis; sépalas 6 , lanceoladas, ápice agudo a obtuso, hispídulas dorsalmente; disco pateliforme; ovário oblato, buladoverruculoso; estiletes unidos, bífidos, patentes; estigmas subcapitados. Faixa central presente em ambas as flores. Cápsula 2,2-2,3×1,8-1,9 mm, subglobosa, superfície bulada. Sementes 1,1-1,2×0,9-1 mm, trígonas, hilo arredondado, subterminal; testa com $10-13$ sulcos transversais e retorcidos revestindo a face dorsal e parte das laterais e com três cavidades de tamanhos irregulares em cada uma das faces laterais, castanho-clara, lustrosa.

Material selecionado: BRASIL. Pernambuco: Igarassu, 16/X/2002, fl., Silva 243 (PEUFR); Paulista, 12/V/2003, fl. fr., Silva 322 (PEUFR); Recife, 29/VI/2003, fl. fr., Silva 356 (PEUFR).

Espécie cosmopolita. Nas Américas, é referida para as Antilhas, Guianas, Guatemala, Honduras, Panamá, Venezuela e Brasil (Webster 1956; Rossignol et al. 1987) crescendo, em geral, nas bordas de florestas litorâneas. No Brasil, ocorre da Amazônia a Santa Catarina em bordas de mata e como invasora em culturas e jardins; em Pernambuco, restringe-se a zona da Mata, habitando as bordas das florestas, e como invasora em cultivos e jardins. Espécie bem delimitada por Rossignol et al. (1987), baseando-se no número cromossômico, aspecto da superfície do fruto e das sementes. Diferencia-se das espécies estudadas pelas folhas oblongo-espatuladas de margens híspidula próximo à base, ovário bulado-verruculoso e anteras com deiscência vertical, além de flores pistiladas solitárias, sésseis e dispostas na parte basal dos ramos ao invés de no ápice dos ramos, como em $P$. stipulatus, P. niruri e P. minutulus.

\section{Agradecimentos}

Ao Dr. Grady Linder Webster "in memorian" (Universidade de Davis, Califórnia, Estados Unidos), 
pela atenção constante e envio de literatura; aos curadores dos herbários, pelo empréstimo do material; ao Programa de Pós-Graduação em Botânica da Universidade Federal Rural de Pernambuco, pelo apoio logístico e presteza dispensada.

\section{Referências bibliográficas}

Allem, A.C. 1977. Notas taxonômicas sobre as tribos Phyllantheae, Dalechampieae e Manihotieae (Euphorbiaceae Juss.) no Rio Grande do Sul. Iheringia 22: 3-5.

Chase, M.W.; Zmartzty, S.; Lledó, M.D.; Wurdack K.J.; Swesen, S.M. \& Fay, M.F. 2002. When in doubt, put it in Flacourtiaceae: a molecular phylogenetic analysis based on plastid $r b c L$ DNA sequences. Kew Bulletin 57: 141-181.

Cordeiro, I. 1992. Flora da Serra do Cipó, Minas Gerais: Euphorbiaceae. Boletim de Botânica da Universidade de São Paulo 13: 169-217.

Cordeiro, I. 1995. Euphorbiaceae. In: B.L. Stannard (ed.). Flora of the Pico das Almas, Chapada Diamantina, Bahia, Brasil. Kew, Royal Botanic Garden.

Holmgren, P.K.; Holmgren, N.H. \& Barnett, L.C. 1990. Index Herbariorum, part 1: The herbaria of the world. New York Botanical Garden.

Lourteig, A. \& O’Donell, C.A. 1942. Euphorbiaceae Argentinae-Phyllantheae, Dalechampieae, Cluytieae e Manihotieae. Lilloa 9: 77-173.

Müeller, J.A. 1863. Euphorbiaceae. Vorlaütige Mitteilungen aus dem für De Candolle's Prodromus bestimmten Manuscrit über diese familie. Linnaea 32: 1-126.

Mueller, J.A. 1866. Euphorbiaceae (Except Euphorbieae) In: De Candolle, Alphonse. Prodromus systematis naturalis regni vegetabilis 15(2): 189-1286.

Mueller, J. 1873. Euphorbiaceae. In: C.F.P. Martius \& A.G. Eichler (eds.). Flora brasiliensis 11(2): 1-752.

Radford, A.E.; Dickson, W.C. \& Massey, J.R. 1974. Vascular plant Systematics. New York, Happer \& Row Publishers.

Rossignol, L.; Rossignol, M. \& Haicour, R. 1987. A systematic revision of Phyllanthus subsection Urinaria (Euphorbiaceae). American Journal of Botany 74(12): 1853-1862.
Santiago, L.J.M. 1988. Estudos preliminares da seção Choretropsis Mull. Arg. Phyllanthus L. (Euphorbiaceae). Bradea 5(2): 44-48.

Samuel, R.; Kathriarachchi, H.; Hoffmann, P.; Barfuss, M.H.J.; Wurdack, K.J.; Davis, C.C. \& Chase, M.W. 2005. Molecular phylogenetics of Phyllanthaceae: evidence from plastid MATK and nuclear PHYC sequences. Americal Journal of Botany 92: 132-141.

Silva, M.J. \& Sales, M.F. 2004. O gênero Phyllanthus L. (Phyllantheae - Euphorbiaceae Juss.) no bioma caatinga do estado de Pernambuco. Rodriguésia 55(84): 105-130.

Smith, L.B. \& Downs, R.J. 1959. Resumos preliminares das Euphorbiáceas de Santa Catarina. Sellowia 11: 155-231.

Torres, D.S.C.; Cordeiro, I. \& Giulietti, A.M. 2003. O gênero Phyllanthus L. (Euphorbiaceae) na Chapada Diamantina, Bahia, Brasil. Acta Botanica Brasilica 17(2): 265-278.

Webster, G.L. 1956. A monographic Study of the West Indian species of the Phyllanthus L. Journal of the Arnold Arboretum 37(2): 91-122, 217-256, 341-357.

Webster, G.L. 1957. A monographic Study of the West Indian species of the Phyllanthus L. Journal of the Arnold Arboretum 38: 51-79, 170-198, 295-375.

Webster, G.L. 1958. A monographic Study of the West Indian species of the Phyllanthus L. Journal of the Arnold Arboretum 39: 49-100, 111-212.

Webster, G.L. 1970. Revision of the Phyllanthus (Euphorbiaceae) in the continental United States. Brittonia 22: 44-76.

Webster, G.L. 2002a. Three new sections and a new subgenus of Phyllanthus (Euphorbiaceae). Novon 12: 290-298.

Webster, G.L. 2002b. A synopsis of the Brazilian taxa of Phyllanthus section Phyllanthus (Euphorbiaceae). Lundelia 5: 1-26.

Webster, G.L. 2003. A synopsis of Phyllanthus section Nothoclema (Euphorbiaceae). Lundelia 6: 19-36.

Webster, G.L. \& Burch, D. 1967. Euphorbiaceae In: Flora do Panamá. Annals of the Missouri Botanical Garden 54: 211-350. 